\title{
Moral Panics and the Copyright Wars
}

\author{
Andrew Katz \\ Partner, Moorcrofts LLP
}

DOI: $\underline{10.5033 / \text { ifosslr.v2i1.36 }}$

\begin{abstract}
Copyright holds a fascination for members of the free and open source community. The copyleft nature of the GPL can exist only because copyright laws exist. ${ }^{1}$ This review considers William Patry's book "Moral Panics and the Copyright Wars", and examines its argument that copyright laws are not fit for purpose.

\section{Keywords}

Book Review, Moral Panics, Copyright Wars, United States

Constitution, Lobbying.

Info

This item is part of the Book Reviews section of IFOSS L. Rev. For more information, please consult the relevant section policies statement.
\end{abstract}

'A "worthless book", "loathsome" and "among the worst books yet written about copyrights"': so said Thomas Sydnor ${ }^{2}$ in his rant about William Patry's latest book. My view: Patry's book is beautifully written. His style is accessible and enjoyable. It is impeccably researched: it is well annotated. ${ }^{3}$ It is generally restrained (although he does allow himself the occasional outburst from

1 Richard Stallman has found himself in favour of arguing against the Swedish Pirate Party's proposals to radically reduce the copyright term across the board, by instituting an increased term of copyright for free software, without which the GPL's ability to enforce software freedom would be severely curtailed.

2 Sydnor's organisation is called the "Progress and Freedom Foundation": a name which I hope I can assume sounds less ludicrous to American ears than to my British ones. Some of its supporters can be found here:

http://www.pff.org/about/supporters.html and include Time Warner, Sony BMG and News International.

3 Almost inevitably, the book contains a few references using Wikipedia links. They are used appropriately (i.e. illustratively, or as a suggestion for further reading, rather than as definitive sources). I'm not at all sympathetic to the argument that wikipedia should never be quoted on the grounds that it is user-generated content and therefore unreliable. However, care needs to be taken when referring to Wikipedia, and I think that links should always be to the version of the Wiki page on the day that it was referenced, or at least there should be a comment in the note, such as www.wikipedia.org/wiki/Aaron_Copland as accessed at 12.01 UTC on 1st April 2009, for example. This minor criticism does feed across to the use of other links: they often have the feel of having been cut and pasted from the address bar of the browser, and therefore may contain the reference variables generating the page in question, rather than a permalink, if one exists, to the page itself. This is more of an observation on the problems of creating persistent links to what may be an impersistent medium, than an indication of any fundamental problems with Patry's work. 
time to time). ${ }^{4}$ I found no error sufficiently serious to make me question its general accuracy (although there were one or two minor issues which I would either classify as typos, or, if this were a newspaper article, should have been picked up by sub-editors). ${ }^{5}$

Why does an accessible yet scholarly, carefully argued yet playful work generate such vitriol in a reviewer?

Patry's central thesis is simple. Copyright exists for a purpose. We must review the laws that create it from time to time to ensure it continues to fulfil that purpose. Any changes to copyright law must only be made with a view to that purpose being fulfilled. If the purpose is not being fulfilled, copyright should be changed, with a view to it continuing to fulfil that purpose. In short copyright should be effective.

Maybe this is such a simple idea, ${ }^{6}$ and one for which I can see no counter-argument, that Sydnor feels that the idea is too obvious. So it is curious that at no point during his review does Sydnor challenge the underlying thesis of the book: that copyright should be effective. Patry demonstrates that copyright is not effective, and by examining how we have reached this state of affairs, leads us into some fairly dark conclusions about the failure of the legislative process. It is maybe no coincidence that another prominent copyright expert, Lawrence Lessig, announced that he was changing his direction from copyfighting to changing congress itself. ${ }^{7}$

The US is a fascinating place to undertake an analysis of the effectiveness of copyright, not only because it's a huge market with no shortage of statistics, but because, in the U.S. Constitution, the wise framers explicitly set out the aim of copyright:

to promote the Progress of Science and useful Arts, by securing for limited Times to Authors ...... the exclusive Right to their ... Writings ${ }^{8}$

The European tradition is less fixed, ${ }^{9}$ and, in the UK, the lack of a written constitution makes it easier for competing arguments as to the purpose of copyright to be aired. Iain Mitchell QC's fascinating article in the previous edition of IFOSSLR discussing the old case of Hinton $-v$ -

4 Pages xxiv and 99 have Patry comparing copyright laws to the sub-prime crisis (and the US Government's reaction to it): maybe not entirely convincingly, but written in an amusingly empurpled fashion.

5 As any Jim White fan knows, David Byrne's record label is called "Luaka Bop", and I'd say that Trent Reznor is NineInch-Nails, as opposed to being their lead singer. Slightly more serious is his contention that Grand Theft Auto sold over $\$ 1 \mathrm{Bn}$ worth of units in 7 months, a figure that seems excessive.

6 This is a dangerous view to take: Bertrand Russell and Alfred North Whitehead famously took over 300 pages to determine, in Principia Mathematica that $1+1=2$.

7 Lawrence Lessig was counsel for Eric Eldred, the petitioner in the supreme court case of Eldred-v-Ashcroft (http://caselaw.lp.findlaw.com/scripts/getcase.pl?court=US\&vol=000\&invol=01-618). The case challenged the constitutionality of the Sonny Bono Copyright Term Extension Act in the US. Lessig announced in 2008 that he was quitting the world of copyright, and had decided to aim his sights on an altogether more significant problem: the corrosive effect on democracy of lobbying, triggered, no doubt, by his losing Eldred.

8 The full text of the relevant part of Section 8 is: "To promote the Progress of Science and useful Arts, by securing for limited Times to Authors and Inventors the exclusive Right to their respective Writings and Discoveries". For ease of reading, I elided the references to inventions, which form the basis of patent protection, as that is irrelevant to the book, and this review.

9 Patry doesn't cover moral rights significantly, which is unsurprising as they are more of a European construct than a US one. 
Donaldson provides an excellent illustration on this point. ${ }^{10}$ But in the US, with this purpose encapsulated in the constitution, Congress is not empowered to pass copyright legislation which does not promote that purpose. Patry, as a U.S.-based lawyer ${ }^{11}$ is given a perfect platform to consider whether the system is working as it should: whether legislators are ensuring that the aims of the legislation are in concord with the aims set out in the Constitution.

Copyright exists to promote the progress of science and useful arts: but note, it does not exist for the benefit of the authors. Benefit to the authors is the means of promoting the progress of science and useful arts. It's not the end in itself. This is quite a subtle idea: the Framers are proposing allowing a little bit of evil (the granting of a limited monopoly) ${ }^{12}$ in order to promote a different public good: the progress of science and useful arts. Like medicine, the dosage is critical.

There are other ways of promoting science and useful arts. Direct state sponsorship or relying on the patronage of wealthy individuals are two of them. But the Framers chose the grant of a limited monopoly. ${ }^{13}$ Why they did so is another, and interesting question, but, leaving that to one side for the moment, in the US, copyright exists to promote that clear purpose. It follows that US copyright law can be tested to see if it fulfils that purpose.

And the conclusion if Patry's book is that it doesn't. To be clear, this book identifies the problem, and although Patry's view is that there's too much copyright law (i.e. the monopoly it grants is too extensive) he doesn't seek, in this book at least, to try to quantify how much less is required to achieve the aims (and never professes to do so, although he does comment on a couple of legislative provisions such as renewal requirement under the 1909 Copyright Act). What is clear is that there is no direct correlation between allowing the authors and artists more rights, and the amount of creation that is going on. In fact, I would tend to put it another way. As many authors and musicians I have spoken to have said, their inner muse compels them to write. The economic problem that they have is better expressed as a lack of disincentive (i.e. "I would be writing music, but I've got to go out and get a job flipping burgers at McDonalds otherwise I'd starve", rather than "if I earned twice as much as I do now from my music, then I'd generate twice as much music", or "my music would be twice as good"). ${ }^{14}$

So if copyright is excessive, how has it reached that state? If the purpose of the Framers was to progress science and useful arts, how have we come to a situation where copyright laws have been enacted which are clearly much more extensive than is necessary to do that?

10 Mitchell QC, Iain G (2009) 'BACK TO THE FUTURE: Hinton v Donaldson, Wood and Meurose (Court of Session, Scotland, 28th July, 1773)', IFOSS L. Rev., 1(2), 111 - 122 DOI: 10.5033/ifosslr.v1i2.23

11 And Senior Copyright Counsel for Google, Inc. to boot (although I must make it clear that he is writing this book in his personal capacity, and he asks us not to ascribe his views to his employer).

12 The use of the term "monopoly" here is not intended to be inflammatory. Neither is the assumption that a monopoly is evil. These issues were well understood around the time of the framing of the US Constitution, by the Founding Fathers, but particularly Thomas Jefferson. Note also Lord Kames's opinion of the Court of Session in Hinton - $v$ Donaldson, in 1773, three years prior to the Declaration of Independence and 14 years before the ratification of the Constitution.

13 So the constitutional question, and the one explored in Eldred - $v$-Ashcroft, is whether Congress has the power to make legislation, for which has been given certain powers for a purpose, but if the exercise of those powers will not advance that purpose.

14 A Confederacy of Dunces was clearly written without the need for any economic incentive, whereas I suspect that The da Vinci Code was. I know which I think is the better book. It's fun to play this game, but I admit it doesn't necessarily stand up to scrutiny. Mark Twain, one suspects, wrote to get paid, and so, quite possibly, did Dickens. 
In Eldred v. Ashcroft, ${ }^{15}$ the dissenting Justice Breyer asked in the wonderfully quotable phrase what incentive an additional 20 years of copyright, to start 50 years after the author's death, would generate:

"What monetarily motivated Melville would not realize that he could do better for his grandchildren by putting a few dollars into an interest-bearing bank account?".

That comment related to a living author; the point was also made that a dead author, whose estate would also benefit from term extension, would find it tricky to dictate a new work from beyond the grave, however incentivised. A number of prominent economists jointly submitted an amicus brief in Eldred v. Ashcroft which claimed (amongst other things) that this economic truism was so ludicrously obvious that Milton Friedman initially refused to be associated with it unless it contained the phrase "no-brainer" ${ }^{16}$ Again: how could an author who was already dead be incentivised to continue to create more by being given an additional 20 years of copyright protection $?^{17}$

Nonetheless, despite the efforts of Lawrence Lessig on his behalf, Eldred failed (by 7-2), and the copyright term in the US was duly extended.

It's difficult see imagine a more dismal and clear failure of evidence-based legislation. ${ }^{18}$ If the legislation envisaged is, in certain significant cases, incapable, on its most generous interpretation, of fulfilling its purpose, then why was it passed? This legislation had received the scrutiny of some

15 See note 7

16 Unfortunately, his wishes couldn't be accommodated: http://www.lessig.org/blog/2006/11/only if the word nobrainer app.html

17 There is, I confess, a problem niggling me here. How do we measure the progress of science and the useful arts? This reminds me of the Laffer-curve debates popular during the Reagan era. It's obvious that if the income tax rate is $99.9 \%$, no-one will be financially incentivised to do any work (and will put a lot of effort into avoiding tax, by employing complex tax mitigation schemes, bartering, or simply evading), so tax revenues will be close to zero. Likewise, if the income tax rate is $0.01 \%$, the percentage of tax raised by government will be so small as to be useless, so somewhere between the two there is a magic figure which is the "right" level of income tax, which will generate a maximum amount of tax. It's very easy to use Laffer-esque arguments to say that if there is a certain amount of monopolistic benefit to copyright holders $x$, then if we increase the amount of monopoly, they will be that much more incentivised. This dramatically over-simplifies a complex multi-dimensional problem, which is probably, by analogy, best illustrated by Martin Gardner's neo-laffer curve: http://en.wikipedia.org/wiki/File:Neo-Laffer-Curve.svg

Finding the appropriate term is by no means easy, and the optimal incentive may vary with the type of work anyway. Another issue is that we tend to assume, copyright in newly created works being, for all practical purposes, infinite, that it retains the same value throughout its economic life, and we tend not to think of what happens towards its expiry.

Lord Kames in Hinton v Donaldson was very aware, even in 1773, of this problem. He said, in effect, that even monopolists, where the monopoly is limited in time, would be competing with the future public domain into which their work would fall. If a work is about to come into the public domain imminently, then people will tend to wait until it does come into the public domain, so that they can get it more cheaply. So if you want to sell a book in the last few months, while it is still in copyright, you will have to lower the price, because as copyright expiry gets closer and closer, the lower the premium that people will be prepared to pay to get their hands on the book now. He argued that if a book was never going to make it into the public domain, then this would "unavoidably raise the price of good books beyond the price of ordinary readers".

The Economists' Brief, and most of Patry's arguments, are based on an economic analysis of the benefit. It deserves further thought, but is there another, better, metric which could be used to determine the optimal level of promotion of science and useful arts?

18 Outside the area of drugs policy. Or penal policy. 
of the finest legal minds in the US, had been through a lengthy process, including challenge in the Supreme Court, and had still been passed. Is this not a monumental failure of the legislative system? A despairing Patry is, therefore, asking why does this happen? How can it happen?

The answer is that for certain parties, namely the copyright rights-holders (who are sometimes, but by no means usually, the authors), extension of the scope of copyright advances their interests, even if that advancement is at the cost of the rest of society, and does nothing to advance the progress of science and useful arts. ${ }^{19}$ Those entities are demonstrably extremely good at persuading legislators to legislate in their interests, and against the interest of society as a whole. ${ }^{20}$

Patry's book, is, in one sense, only peripherally about copyright. What he explains so lucidly and compellingly is that copyright gives us the clearest possible example of a case where legislators are legislating directly against the public interest, in cases where there is no argument of any substance to support their view. In doing so, he carefully considers the toolkit which the lobbyists use.

A significant part of the book deals with the power of metaphor. Human beings are wonderful pattern recognition machines. One consequence of this is that we are good at reasoning by analogy, but just as we are easily capable of seeing patterns where none exists, we are equally good at taking analogy too far. One of the favourite metaphors of those seeking to extend the reach of copyright is the "fruit" metaphor, frequently recast in similarly agrarian style as reaping what one has sown. A recent example of this is the Irish case of EMI $v$ Eircom. ${ }^{21}$ In which Charleton $\mathrm{J}$ repeatedly talks about "fruits", and bases his judgement accordingly. Unfortunately, the Irish constitution is silent as to copyright (including as to its purposes), so we cannot apply Eldred $v$ Ashcroft by analogy.

Metaphors are a shortcut to thinking: that is not necessarily a bad thing. The twin constraints of time and cranial capacity mean that no ordinary person is capable of deriving any moderately complex concept from first principles (including, presumably, legislators), and apt metaphors are a useful way of achieving this. However, extending the metaphor too far is fraught with danger. Patry effectively explains the persuasive power of some of these metaphors, and carefully explains

19 Note that incumbents generally welcome regulation of any sort, as it tends to reinforce their oligopoly (incumbents are normally consulted on regulation anyway, but even so, they are best placed to be able to set up the practices and procedures to enable them to deal with it. The costs of complying will be fairly similar for each party anyway, so it will not affect the competitive dynamic, such as it is, between the members of the oligopoly). However, regulation does create a barrier for entrants, who are much greater threat to incumbents, as they are much more likely to behave disruptively,. Note also, that an oligopoly will tend to generate unjustifiably large revenues. Dismantling the oligopoly (even if good for consumers) may be seen as bad by the government department which is regulating them (headlines saying "Ofcom regulation causes mobile telephone revenue to decrease by $20 \%$ " are, illogically, not published as good news), so oigopolies are very powerful. Finally, the super-revenue which oligopolies generate may make some things possible that otherwise would not have been. For example it may not have been possible to make the hugely expensive* film "Avatar" in the absence of a Hollywood oligopoly. However, this is not an argument in favour of oligopolies. To quote Eben Moglen: "Without hydraulic despotism and the divine right kingship of the pharaoh, we will underproduce pyramids. Now, we've been underproducing pyramids for three thousand years, and pyramids are beautiful but it isn't hurting us."

* At least the studio saw the benefits of free software. Avatar was rendered on a 35,000 core farm running Ubuntu (http://blog.dustinkirkland.com/2010/01/39000-core-ubuntu-cluster-renders.html)

20 I suspect that Sydor may secretly rate Patry's book as it provides him with a handy "how to" guide to subvert legislators, much as the UK government seems to regard Orwell's Nineteen-Eighty Four as a useful instruction manual.

21 [2010] IEHC 108 Charleton J 
why the "fruits" metaphor is inaccurate and misleading.

The book also deals with the persuasive idea that copyright is some sort of natural right: a property right, by which creators should be entitled to be in sole control of their creators. This is a persistent theme in the book. In theory, in American law, it should be irrelevant, unless the proponent is arguing for a constitutional amendment. The constitution makes it clear that copyright is not a natural property right, and therefore legislation short of a constitutional amendments should not try to make it so.22

The third weapon which, according to Patry, pro-copyright lobbyists employ is the "moral panic" of the title: examples include John Philip Sousa in the late 19th century and early 20th centuries, ${ }^{23}$ Jack Valenti in the 20th century ${ }^{24}$ and Thomas Sydnor in the $21^{\text {st }} \cdot{ }^{25}$ A moral panic is an unjustified extrapolation from current circumstances to inevitable disaster, and is a well-worn tool of rhetoricians.

Copyright is a technical issue which a relatively small number of people (the readers of IFOSSLR not among them) understandably fail to get excited about. If the rights-holders are able to generate sufficient moral panic to ensure the passage of legislation which will fail to fulfil its intended purpose ${ }^{26}$ then what does this say about the passage of other legislation, where the issues generate more perceived concern in the electorate, such as the Obama's healthcare reforms, or, of more international interest, drug legislation in general? As lawyers as well as concerned citizens, we need to understand how the machinery of legislation and governance can go so wrong.

Patry's book, therefore, advises us to be cynical. Well-funded vested interests are capable of

22 In a sense, the idea that copyright is property is also a metaphor which has gone too far. The Founding Fathers sensibly avoided this analogy in the US Constitution, but in contrast, the UK Copyright Act specifically refers to copyright as a property right (section 1), and while this usefully imbues copyright with some characteristics of property, such as the ability for it to be assigned to bequeathed, it also strengthens the arguments of those who believe that as a property right, copyright is a natural right, and that any encroachment on that right is a form of unjustified government interference from a free market perspective. Patry persuasively argues that, in direct contrast, copyright is nothing but government interference and therefore, and equally from a free market perspective it is the existence and extent of copyright that need to be justified, not any encroachment or limitation on in. This is surely the strongest possible example of the power of metaphor: by a simple recharacterisation from "property" to "government programme", copyright can be turned from something which free-marketers passionately defend, to something which the same people would condemn.

23 "These talking machines are going to ruin the artistic development of music in this country. When I was a boy...in front of every house in the summer evenings, you would find young people together singing the songs of the day or old songs. Today you hear these infernal machines going night and day. We will not have a vocal cord left. The vocal cord will be eliminated by a process of evolution, as was the tail of man when he came from the ape". John Philip Sousa in a submission to a congressional hearing in 1906, arguing against mechanical playback devices such as player pianos and gramophones.

24 "the VCR is to the American film producer and the American public as the Boston strangler is to the woman home alone": Jack Valenti, for the MPAA, giving testimony to the House of Representatives in 1982.

25 The title of one of Sydnor's recent papers is sufficient: "Inadvertent File Sharing over Peer-to-Peer Networks: How It Endangers Citizens and Jeopardizes National Security" (29 July 2009). Available at SSRN: http://papers.ssrn.com/sol3/papers.cfm?abstract_id=1443289

26 The Digital Economy Act 2010 has just been passed in the UK, which seeks amongst other things, to grant draconian and disproportionate powers on rights-holders to disconnect copyright infringers without due process. From a technical perspective, it's trivially easy to evade the detection measures that are put in place, and the passage of the Act provides a classic example of the effectiveness of well orchestrated lobbying, and the craven ability of parliament to reject democratic process and subject the bill to proper scrutiny. The lobbyists employed every weapon in the armoury delineated by Patry. 
subverting the legislative process. Patry's book tells us how.

One issue which I would like to have seen examined more closely is the fact that income from copyright royalties is easily measurable: losses arising from a decrease in the scope of the public domain are not. Royalties are taxable. Thus an increase in the extent and scope of copyright may well result in a measurable increase in government revenue attributable to one measure. ${ }^{27}$ Even though a decrease in the scope of copyright benefits the economy as a whole, that benefit is much more difficult to quantify than the specific decrease in tax take on recording industry profits, for example, and therefore are less likely to spur any individual minister, looking for personal advancement, into action.

I recommend this book to anyone interested in copyright, politics, freedom, democracy, the legislative process, corruption and human nature. It should be required reading for legislators.

Patry has suggested that his next book ${ }^{28}$ may suggest how we can fix the problem. I'm looking forward to it eagerly.

27 A related issue is that by enclosing any commons, what was freely available starts generating revenue and becomes taxable. It is also an artificial way of increasing a country's GDP (a statement which, perhaps erroneously, suggests that GDP is not an erroneous concept in the first place). Any economic activity, whether it tends to increase overall wealth of a nation or not, adds to GDP, as Partha Dasgupta recently pointed out (summarised by George Monbiot here: http://www.guardian.co.uk/commentisfree/2010/jan/04/standard-of-living-spending-consumerism)

28 Tentatively entitled "How to Fix Copyright": http://moralpanicsandthecopyrightwars.blogspot.com/2009/11/my-nextbook.html 


\section{Licence and Attribution}

This paper was published in the International Free and Open Source Software Law Review, Volume 2, Issue 1 (June 2010). It originally appeared online at http://www.ifosslr.org.

This article should be cited as follows:

Katz, Andrew (2010) 'Moral Panics and the Copyright Wars', IFOSS L. Rev., 2(1), pp $69-76$

DOI: $\underline{10.5033 / \text { ifosslr.v2i1.36 }}$

Copyright () 2010 Andrew Katz.

This article is licensed under a Creative Commons UK (England and Wales) 2.0 licence, attribution, CC-BY.

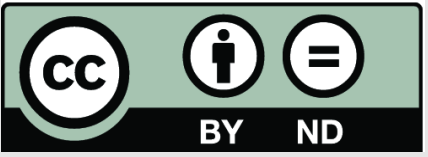

